Chapman University

Chapman University Digital Commons

Education Faculty Articles and Research

College of Educational Studies

$10-5-2015$

\title{
The Role of Perception, Interpretation, and Decision Making in the Development of Beginning Teachers' Competence
}

\author{
Rossella Santagata \\ University of California, Irvine \\ Cathery Yeh \\ Chapman University,yeh@chapman.edu
}

Follow this and additional works at: http://digitalcommons.chapman.edu/education_articles

Part of the Educational Assessment, Evaluation, and Research Commons, Educational Methods Commons, Elementary Education and Teaching Commons, and the Science and Mathematics Education Commons

\section{Recommended Citation}

Santagata, R. \& Yeh, C. (2016). The role of perception, interpretation, and decision making in the development of beginning teachers' competence. ZDM Mathematics Education, 48(1): 153-165. doi: 10.1007/s11858-015-0737-9

This Article is brought to you for free and open access by the College of Educational Studies at Chapman University Digital Commons. It has been accepted for inclusion in Education Faculty Articles and Research by an authorized administrator of Chapman University Digital Commons. For more

information, please contact laughtin@chapman.edu. 


\section{The Role of Perception, Interpretation, and Decision Making in the Development of Beginning Teachers' Competence}

\section{Comments}

This is a pre-copy-editing, author-produced PDF of an article accepted for publication in ZDM, volume 48, issue 1, in 2016 following peer review. The final publication is available at Springer via http://dx.doi.org/ $10.1007 /$ s11858-015-0737-9.

\section{Copyright}

Springer 


\title{
The Role of Perception, Interpretation, and Decision Making in the Development of Beginning Teachers' Competence
}

\begin{abstract}
This study investigates beginning U.S. elementary teachers' competence for teaching mathematics and its development during teacher preparation and into the first two years of fulltime teaching. Data are drawn from three longitudinal case studies and include the Classroom Video Analysis survey, classroom observations and interviews about teachers' instructional decisions, and whole-day shadowing. A multi-case study design was used to examine the processes of perception, interpretation, and decision making in participants' comments on video clips of teaching episodes and in reflections about their own teaching. Findings support the central role of these processes in teacher competence and the generative power of reflections revolving around student thinking and tools, such as classroom discourse and visuals. Teachers' communities also played an important role in teachers' decision making. A model of teacher competence from a situated perspective is proposed and the Classroom Video Assessment is discussed as a measure of teacher competence in context.
\end{abstract}

Keywords: Teacher competence; video; video analysis; beginning teachers; longitudinal study; mathematics teaching.

Rossella Santagata \& Cathery Yeh

University of California, Irvine 


\section{The Role of Perception, Interpretation, and Decision Making in the Development of Beginning Teachers' Competence}

\section{Introduction}

Many countries, particularly in the West, have lamented weaknesses in ways mathematics is taught and learned in schools (European Mathematical Society, 2006; Hiebert et al., 2005; Jaworski, 2006). Research evidence is accumulating on teachers' lasting impact on children's learning experiences (Chetty, Friedman, \& Rockoff, 2011). Yet, conceptualizations of teacher professional competence remain limited. It is still not clear what makes a teacher effective and how competence interacts with the settings in which teachers work. In this paper, we examine teacher competence through case studies of three novice teachers. Rather than focusing on expert competence, we examine the development of competence. We study the beginning of teacher professional careers as it offers an interesting viewpoint into competence: knowledge and beliefs developed during teacher preparation encounter the reality of schools as teachers begin their professional lives. Interactions between these facets of competence and work settings are thus particularly evident at this stage of teachers' careers. We believe that attention to the dynamic nature of competence may shed light on aspects not yet thoroughly examined. The study focuses on three particular skills that have recently received attention in mathematics teacher education research: perception, interpretation, and decision making. We ask: What roles do these skills play in novice teachers' competence and in its development? And can these skills be measured through a video-based survey?

\subsection{Mathematics Teacher Competence: The State of the Art}

Research on teacher competence has largely focused on teacher cognition. In the last two decades, research efforts in mathematics education have expanded greatly our understanding of 
the nature and types of knowledge that make teachers effective. A prominent example is the research conducted by a team at the University of Michigan in the United States led by Deborah Ball. This group extended Shulman's conceptualization of pedagogical content knowledge (Shulman, 1987) and studied systematically teachers' mathematics knowledge for teaching (MKT), offering a detailed conceptualization of its components (Ball, Thames, \& Phelps, 2008). MKT was also found to be positively related to quality of instruction (Hill et al., 2008) and student learning (Hill, Rowan, \& Ball, 2005). Another focus has been teacher beliefs. Studies of teachers' beliefs, spanning over fifty years, suggest that teachers' beliefs about the nature of mathematics and about the teaching and learning of mathematics affect their teaching practices (Fives \& Beuhl, 2012; Thompson, 1992).

Scholars in the field have called for an expansion of these conceptualizations, from a focus on individual teachers' cognition, knowledge, and beliefs and their typology into discussion of ways these translate into decisions and actions in the classroom (Borko, Roberts, \& Shavelson, 2008). There have also been calls for more attention to specific circumstances (Blömeke, Gustafsson, \& Shavelson, 2014; Blömeke, Hsieh, Kaiser, \& Schmidt, 2014) and to the broader historical/political contexts in which teachers' work takes place (Gutiérrez, 2013).

In this paper, we draw on a conceptualization of teacher competence recently proposed by Blömeke and colleagues (2014). These authors studied extensively competence in the context of the international project "Teacher Education and Development Study in Mathematics" (TEDS-M: Blömeke, Kaiser, \& Lehmann, 2010) and its follow-up “TEDS-FU.” (Kaiser, Blömeke, Busse, Döhrmann, \& König, 2014). Figure 1 represents the proposed model of competence. This model aims to resolve the common dichotomy between cognitive and situated perspectives in the study of teachers and their work. Competence is seen as a continuum starting 
from cognitive and affect-motivation aspects - which the authors define as dispositions, - moving to situation specific skills that lead to performance (i.e., observable behavior) in the classroom. Novice-expert research in cognitive psychology (Chi, 2011) informs the conceptualization of these situation-specific skills that the authors introduce as the PID model: (1) Perceiving particular events in an instructional setting; (2) Interpreting the perceived activities in the classroom; and (3) Decision Making, either as anticipating a response to students' activities or as proposing alternative instructional strategies. Compared to novice teachers, expert teachers perceive, interpret, and anticipate what might happen in a teaching situation more quickly, accurately, and holistically (Kaiser et al., 2014). These authors call for additional research to better understand the role of situation specific skills as in-between processes that explain how dispositions are translated into classroom performance.

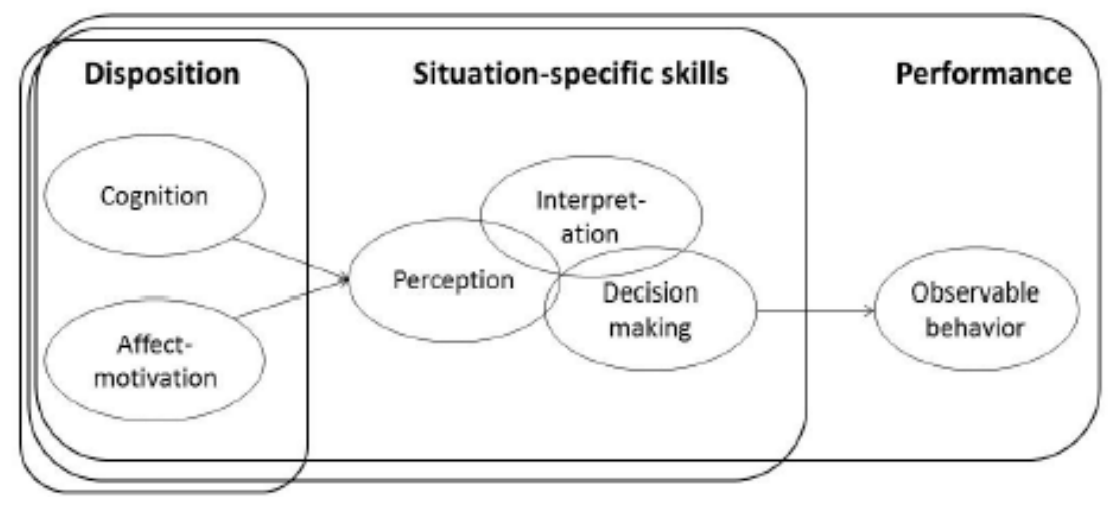

Figure 1. Teacher Competence Model drawn from Blömeke, Gustafsson, \& Shavelson (2014).

\subsection{Teacher Competence and Teacher Noticing}

A body of work focused on similar skills is research on teacher noticing (Sherin, Jacobs, \& Philipp, 2011). Sherin and colleagues define noticing as professional vision: a professional lens through which teachers come to view teaching. In this work, emphasis is placed on teachers' abilities to attend to and interpret student thinking in the midst of instruction. The 
development of noticing skills has been related to changes in teachers' classroom practices specifically in relation to the level of their responsiveness to student thinking (Sherin \& van Es, 2009).

Several researchers have built on the notion of teacher noticing in different ways, as illustrated in a recent volume edited by Sherin, Jacobs, and Philipp (2011). Particularly relevant to the set of situation-specific skills described by Blömeke and colleagues (2014) is the work by Jacobs, Lamb, Philipp, and Schappelle (2011). These authors have highlighted the importance of teachers' ability to respond to student thinking during instruction. Their definition of noticing includes three processes that are tied together: attending to children's strategies; interpreting student responses, work, and solution methods in terms of the mathematical understandings they reveal; and deciding in the moment how to respond on the basis on children's understandings.

One of the differences between teacher noticing and the PID model proposed by Blömeke and colleagues (2004) is that while most of the research on noticing focuses on student mathematics thinking, the situation-specific skills in Blömeke et al.'s PID model comprise all aspects of quality mathematics teaching and include, for example, individual learner support, cognitive activation of learners, and classroom management.

\subsection{Analysis Abilities}

We have also conducted research that is relevant to the PID model and focuses on teachers' abilities to analyze teaching. In this work, we have defined analysis skills as the abilities to: (1) attend to the details of the teaching-learning process (such as student thinking, teacher questions, and math content); (2) elaborate on these details to examine the impact of teacher decisions on student progress towards lesson learning goals; and, (3) propose improvements in the form of alternative strategies teachers might adopt to enhance students' 
learning opportunities (Santagata, Zannoni, \& Stigler, 2007; Yeh \& Santagata, 2014). Although we use different terms, there is clear parallelism between attending and perception, elaborating and interpretation, and proposing improvements and decision making as they are proposed by Blömeke and colleagues and as they are discussed in our work. We will thus use the terms above interchangeably in what follows.

We have used a tool, "the Lesson Analysis Framework," to guide teachers' analysis of videos of teaching, both of others and of their own. The framework consists of four sets of questions teachers are asked to consider: (1) What are the main learning goals of the lesson? (2) Did the students make progress towards the learning goals? Did they encounter difficulties? What evidence do you have? What evidence is missing? (3) Which instructional decisions assisted students in making progress towards the goals, which did not? And (4) How can the lesson be improved? What alternative strategies could the teacher use and how would these assist students in making progress toward the learning goal?

We have investigated the use of this tool in both in-service and pre-service teacher programs (Santagata, 2009; Santagata \& Guarino, 2011). In multiple studies, we have examined the sub-skills teachers need to answer effectively each question above. These are grounded in the processes of attending, elaborating, and proposing improvements. For example, to be able to specify the learning goals, teachers need to attend to the specifics of the mathematical content and unpack mathematical ideas to identify major building blocks. To assess students' progress toward the learning goal, teachers need to attend to the details of students' utterances and written work and elaborate on this evidence as a window into mathematical understandings or misconceptions. They also need to identify evidence of student learning that is relevant to a specific learning goal (Yeh \& Santagata, 2014). To analyze the impact of teaching on learning, 
teachers need to elaborate on the connection between certain learning outcomes and particular tasks or questions at the core of the lesson. Finally, to propose instructional improvements, teachers must develop repertoires of strategies and understand how these facilitate students' progress towards specific learning goals.

Our programs have incorporated opportunities for teachers to develop these sub-skills with the ultimate objective of preparing them to conduct systematic analyses of their own teaching independently. Studies have shown that both pre-service and in-service teachers can learn to use the Lesson Analysis Framework effectively (Santagata, 2009; Santagata \& Guarino, 2011).

\subsection{Study Purposes and Research Questions}

In this paper, we take a step forward. Through a longitudinal examination of novice teachers' competence, we study the abilities to attend, elaborate, and propose improvements -the situation-specific skills (perception, interpretation, and decision making) described by Blömeke and colleagues - in three teachers from the beginning of teacher preparation through the first two years of full-time teaching. We take this multi-case study approach to test the model proposed by Blömeke and colleagues (2014) and closely examine the role of situation specific skills in teachers' practices. We consider this approach complementary to large-scale studies of teacher competence in that it permits (a) the unveiling of how specific work settings interact with teacher competence and (b) the testing and possible amendments to the existing theoretical model in the form of hypotheses that can later be tested on a larger scale. The longitudinal nature of the study also allows us to examine the development of teacher competence over time and the underlying processes and decisions that make this development possible, or at times difficult. 
A second purpose of this paper is to discuss video as a tool to measure teacher competence in context. We utilized the Classroom Video Analysis survey (CVA: Kersting, 2008), a video-based assessment of teachers' usable knowledge of mathematics teaching. Prior studies have shown that teachers' performance on the CVA is positively related to their students' learning as mediated by the quality of their instruction (Kersting et al., 2012). What distinguishes this idea of "usable" knowledge from other more typical conceptions of knowledge is that it is triggered by specific teaching situations, and perception, interpretation, and decision making are the processes at its core (Kersting, 2008).

In addition to reporting participants' scores on the CVA, we also report on qualitative analyses of the participants' CVA responses at four points in time: prior to and at completion of teacher preparation and at the end of each of the two years of full-time teaching. CVA data is triangulated with interview and observation data. While the CVA assesses competence through commentaries on lessons taught by others, the interviews capture teachers' reflections on their own teaching. The comparative analysis of data collected through the CVA, which can be administered on a large scale, and interviews and observations that are more commonly used in qualitative studies, allowed us to reflect on the advantages and limitation of the CVA.

In sum, the present study answers the following questions:

(1) What roles do perception, interpretation, and decision-making skills play in novice teachers' competence and in its development?

(2) Can these skills be measured through a video-based measure (i.e., the CVA)? How does this measure compare to qualitative examination of teacher competence in context?

\section{Methods}

\subsection{Participants and Context}


The present study builds on the first phase of a larger project (i.e., the Learning to Learn from Mathematics Teaching project) that investigated the impact of a video-enhanced mathematics methods course on pre-service teachers' (PST) knowledge, beliefs, and teaching practices at the end of teacher preparation and during the first two years of teaching. Twentynine teachers attended the course as part of their teacher preparation program and 10 found full time jobs following graduation. Among these, three were selected as case study participants for the present study. Selection consideration included distance of the school (to keep follow-up costs affordable), the school's socio-economic context, and ethnic composition of the student population. We were interested in examining the job experience of teachers who taught in schools that represent the local community's diversity. As shown in Table 1, the school's demographics ranged from $20 \%$ to $75 \%$ of English language learners and from $18 \%$ to $89 \%$ of students who received free or reduced lunch, a proxy used in the United States to represent students' family income. The schools' racial/ethnic composition was also diverse. We collected information about the participants' previous teaching experiences and professional development opportunities (see Table 1). These will be discussed in detail in the findings section. 
Table 1

Participating Teachers' Background and School Information

\begin{tabular}{|c|c|c|c|c|}
\hline \multirow[t]{2}{*}{ Name } & \multirow{2}{*}{$\begin{array}{l}\text { Prior } \\
\text { Teaching } \\
\text { Experience }\end{array}$} & \multicolumn{3}{|c|}{ Full-Time Teaching Job } \\
\hline & & Grade & $\begin{array}{c}\text { \% English Language Learners and Primary } \\
\text { Language(s), } \\
\text { School Ethnic Composition, and } \\
\% \text { Free/Reduced-Cost Lunch }\end{array}$ & $\begin{array}{l}\text { Professional } \\
\text { Development } \\
\text { Opportunities }\end{array}$ \\
\hline Tracy & $\begin{array}{l}\text { Tutor; } \\
\text { Teacher } \\
\text { assistant }\end{array}$ & $4^{\text {th }}$ & $\begin{array}{l}\text { English language learners: } 44 \% \\
\text { Primary language(s) of English Learners: } \\
\text { Spanish } \\
\text { School demographics: } 83 \% \text { Latino, } 7 \% \\
\text { African American, } 4 \% \text { White; } 6 \% \text { Other } \\
\text { Free/Reduced -Cost Lunch: } 86 \%\end{array}$ & $\begin{array}{l}\text { Cognitively Guided } \\
\text { Instruction } \\
\text { workshops }\end{array}$ \\
\hline Reina & $\begin{array}{l}\text { Teacher } \\
\text { assistant; } \\
\text { Tutor; } \\
\text { English } \\
\text { teacher } \\
\text { abroad }\end{array}$ & $\mathrm{K}$ & $\begin{array}{l}\text { English Language Learners: } 20 \% \\
\text { School demographics: } 35 \% \text { Asian, } 34 \% \\
\text { White, 14\% Latino, } 3 \% \text { African/African } \\
\text { American, } 11 \% \text { Other } \\
\text { Free and Reduced Lunch: } 18 \%\end{array}$ & $\begin{array}{l}\text { Cognitively Guided } \\
\text { Instruction } \\
\text { workshops }\end{array}$ \\
\hline Karen & $\begin{array}{c}\text { Tutor; Sports } \\
\text { coach }\end{array}$ & $\mathrm{K}$ & $\begin{array}{l}\text { English Language Learners: } 75 \% \\
\text { Primary language(s) of English Learners: } \\
\text { Spanish } \\
\text { School demographics: } 69 \% \text { Latino, } 30 \% \\
\text { African American } \\
\text { Free and Reduced Lunch: } 89 \%\end{array}$ & $\begin{array}{l}\text { School-based } \\
\text { professional } \\
\text { development }\end{array}$ \\
\hline
\end{tabular}


The participants attended an intensive one-year, post- baccalaureate, full-time elementary teacher certification program (kindergarten through sixth grade, children from 5 to 12 years old) at a public university in the United States. The program emphasizes developing proficiency in four key areas: (1) developing an inquiry stance, (2) supporting second-language learners, (3) collaborating with colleagues to continually improve practice, and (4) appreciating the resources students bring to the classroom. Pre-service teachers experience a full year of fieldwork in public schools as well as two quarters (i.e., 20 weeks) of mathematics methods courses (30 hours each quarter, structured in 3-hour weekly meetings). The curriculum combined activities that allowed the analysis of mathematics teaching with opportunities to practice student-centered teaching in classroom settings. Video of individual student interviews and teaching episodes was used extensively to provide images of mathematics teaching that is responsive to student thinking and to facilitate a collaborative process of analysis. The Lesson Analysis Framework guided the analysis of student thinking, mathematical ideas, and the interrelation between teachers' decisions and student learning. Tasks were planned to gradually scaffold PSTs from supported to independent analyses and from analyses of others' lessons to analysis of their own teaching. The end goal was for this deliberate and systematic process to become a part of PSTs' repertoire of practices.

\subsection{Measures}

2.2.1 Classroom video analysis survey. Participants completed the CVA survey prior to and at the end of teacher preparation, and at the end of each of the two years of full-time teaching. As mentioned above, the CVA measures teacher usable knowledge of mathematics teaching through their ability to analyze episodes of classroom lessons (Kersting, 2008). For the purposes of this paper, we present data we collected through five short video clips, each 1-3 
minutes in length, from second through sixth-grade classrooms on the topic of whole number operations. PSTs viewed the video clips on a web-based platform and typed written comments in response to the prompt, "Discuss how the teacher and the student(s) interact around the mathematical content." Although the tested video clips are not publicly released, similar clips with sample teacher comments are accessible at www.teknoclips.org/examples/.

Participants' responses were scored according to the instrument's 3-point rubrics. These capture perception, interpretation, and decision making skills through the assessment of teachers' abilities to (1) attend to the mathematics content at the center of the interaction, (2) elaborate on students' mathematical thinking and learning as made evident in the video clips, (3) propose improvements, and (4) elaborate and interpret the interaction observed in the video beyond a mere description of what was observed. Each comment received a score from 0 to 2 for each of the four rubrics to capture the extent to which teachers demonstrated the abilities defined by each rubric. Two independent raters scored all comments. Inter-rater reliability, measured as percent agreement ranged from $83.7 \%$ to $88 \%$ across the four rubrics and time points. In case of disagreements between raters, a third rater reviewed the comments and made the final decision. Each participant's scores across the five clips were added together to create a score for each analysis ability that ranged from 0 to 10 . Finally, scores across the four rubrics were added to create a total CVA score that could range from 0 to 40 . In addition, for the purpose of this paper, we analyzed the participants' written comments qualitatively so we could triangulate evidence of their perception, interpretation, and decision-making skills collected through interviews.

2.2.2 Observations and post-lesson interviews. After graduation, each teacher was visited at her school site three times a year for two years: at the start, midway, and during the last month of the school year. During each visit, a mathematics lesson was videotaped and a post- 
lesson interview was conducted. Prior to each visit, teachers were asked through email to share their lesson plan. Interviews were semi-structured and recorded and transcribed verbatim. Four sets of questions were posed during the interview: (1) What was the main learning goal of this lesson? (2) How did it go? What was surprising? What worked as planned? What didn't? (3) What would you do differently, if you were to teach this lesson again? And (4) What did you learn from teaching this lesson? These questions provided a viewpoint into teachers' perception (i.e., what do teachers attend to as they consider what worked and what didn't in their lesson?), interpretation (i.e., how do teachers elaborate on what happened in their lesson?), and decision making (i.e., what improvements do teachers consider?). In addition, on the visit, teachers were shadowed for the entire school day and an in-depth interview was conducted. This included questions about their teaching experience during the year, their self-efficacy, perceived contributors to their competence (methods courses, fieldwork experiences, or other), collaboration opportunities with colleagues, and school culture and support. Although our data includes videotaped mathematics lessons and field notes, for the purposes of this paper, these data sources only served as context for situating and interpreting teachers' interview data. Analyses focused on the CVA comments and interviews. The following figure summarizes the data collection sources and timeline. 
Teachers' Competence, 15

Figure 2. Data sources and data collection timeline from prior to teacher preparation (Time 1), to end of teacher preparation (Time 2), to first two years of full-time teaching (Time 3 and 4). 


\subsection{Study Design and Procedures}

A multi-case study design (Yin, 2003) was used to answer the study questions. Data analyses were conducted through a two-phase process. First, each participant's CVA written comments and interview transcripts were subjected to a vertical analysis (Miles \& Huberman, 1994); in other words, they were examined independently and across time. A second phase was then carried out through a comparative or horizontal analysis (Miles \& Huberman, 1994) across the three cases.

In the first phase, four steps were followed. Each source of data was reviewed and memos were created to summarize ways perception, interpretation, and decision making processes were evident. Tentative thematic codes (Corbin \& Strauss, 2007) were developed to capture the focus of teachers' processes. Specifically, during this first step we first kept track of all themes discussed by the participants. Second, units of analysis based on topic segmentation (i.e., discussion of successful aspects of the lesson; discussion of lesson goals and purposes) were created for the interview transcripts. CVA written comments were generally brief (approximately 70 words on average) so each comment was treated as a unit of analysis. Third, each unit segment was analyzed in terms of the themes emerged during step 1 with a focus on perception, interpretation, and decision making. Larger categories were created that captured the emphasis of a few themes. Within these larger thematic categories, text was highlighted that referred to teachers' perception, interpretation, and decision making. Throughout the analysis process, constant comparative analysis (Glaser \& Straus, 1968) was used, coded segments were compared to each other and coding revisited several times to account for increased familiarity with the data and researchers' understanding. In addition, analyses were triangulated by constantly comparing CVA comments and interview transcripts. In the fourth and final step, 
summaries were written for each teacher across data sources - highlighting their attending, interpreting, and decision making and illustrative quotes were selected. This summary also included a description of how these processes changed over time.

In the second phase of analysis, a comparative or horizontal analysis (Miles \& Huberman, 1994) was carried out in which individual case themes were compared across the three cases. Cross-case displays and matrices were then constructed drawing from the individual cases' summaries to examine patterns and themes across cases. Authors reviewed data independently and met regularly to discuss emerging themes, coding categories, and interpretations. Agreement was reached through consensus. When divergent opinions existed, they were considered by reviewing the data multiple times until agreement was reached (Yin, 2003).

\section{Findings}

\subsection{Classroom Video Analysis Findings}

3.1.1 Quantitative scores. As mentioned above, the total CVA score was the sum of the four scores teachers received that captured various aspects of their perception, interpretation, and decision-making skills. The total CVA score improved for all participants over time. Given the targeted experiences provided during teacher preparation, improvements from prior to the end of teacher preparation were expected. However, improvements from T2 to T4 indicate that teachers continued to improve their usable knowledge of mathematics teaching during their first two years of full-time teaching.

Participants differed in their initial knowledge and development. In particular, Tracy demonstrated relatively high levels of analysis abilities at the start of teacher preparation. While all three improved over time, Reina showed the most improvement from the end of teacher 
preparation to the end of her first year of teaching, and Karen showed the least improvement overall. With a couple of exceptions, participants' scores on each of the four rubrics also improved over time. This indicates that teacher preparation first, and on-the-job opportunities later, provided opportunities for teachers to develop their abilities to unpack the mathematics content, analyze students' mathematical thinking, interpret the interactions observed, and suggest improvements. Changes in scores might be linked to their professional development experiences, to opportunities to increase their knowledge through their daily work in the classroom, or to both.

We collected information about each teacher's participation in professional development (see Table 1) that could in part explain improvements in CVA scores. Specifically, while Tracy did not attend any formal professional development during the first year of teaching, she enrolled in a Cognitively Guided Instruction (CGI) professional development program during her second year. The CGI program is designed to strengthen teachers' knowledge of children's development of number concepts and skills and to improve teachers' capacity to build instruction on students' own thinking. The improvement in Tracy's CVA scores at the end of the second year of teaching might be in part due to these experiences. Reina attended CGI professional development during her first year of teaching and was also involved in a series of other professional learning groups that met regularly throughout the year where teachers collectively lesson planned and reflected on their teaching. This might in part explain the improvement in her CVA scores from the end of teacher preparation to the end of the first year of teaching. Finally, Karen had limited opportunities to develop her analysis abilities in professional development settings. During both years, she attended school-mandated training on teaching pedagogy that was not specific to developing knowledge of mathematics content or to interpreting the details of students' 
mathematical thinking. Nonetheless, a minor improvement was evidenced in her case as well at the end of the second year of full-time teaching. Interviews indicate that all three participants also learned from their daily work in the classroom. We will return to this point later. Table 2 below reports the CVA scores for each participant over the four data collection times. 
Table 2

Participants' Scores on the CVA Rubrics and Total CVA Scores across Time

\begin{tabular}{|c|c|c|c|c|c|c|c|c|c|c|c|c|c|c|c|c|c|c|c|c|}
\hline $\begin{array}{r}\text { Scoring } \\
\text { Rubrics } \\
\text { and range }\end{array}$ & \multicolumn{4}{|c|}{$\begin{array}{l}\text { Math Content } \\
(0-10)\end{array}$} & \multicolumn{4}{|c|}{$\begin{array}{l}\text { Student } \\
\text { Thinking } \\
(0-10)\end{array}$} & \multicolumn{4}{|c|}{$\begin{array}{l}\text { Improvement } \\
\text { Suggestions } \\
(0-10)\end{array}$} & \multicolumn{4}{|c|}{$\begin{array}{l}\text { Depth of } \\
\text { Interpretation } \\
(0-10)\end{array}$} & \multicolumn{4}{|c|}{$\begin{array}{l}\text { Total CVA Score } \\
(0-40)\end{array}$} \\
\hline Data & $\mathbf{T}$ & $\mathbf{T}$ & $\mathbf{T}$ & $\mathbf{T}$ & $\mathbf{T}$ & $\mathbf{T}$ & $\mathbf{T}$ & $\mathbf{T}$ & $\mathbf{T}$ & $\mathbf{T}$ & $\mathbf{T}$ & $\mathbf{T}$ & $\mathbf{T}$ & $\mathbf{T}$ & $\mathbf{T}$ & $\mathrm{T}$ & $\mathbf{T}$ & $\mathbf{T}$ & $\mathbf{T}$ & $\mathbf{T}$ \\
\hline $\begin{array}{r}\text { Collection } \\
\text { Time } \\
\end{array}$ & 1 & 2 & 3 & 4 & 1 & 2 & 3 & 4 & 1 & 2 & 3 & 4 & 1 & 2 & 3 & 4 & 1 & 2 & 3 & 4 \\
\hline Participant & & & & & & & & & & & & & & & & & & & & \\
\hline Tracy & 2 & 5 & 3 & 7 & 3 & 5 & 5 & 7 & 2 & 5 & 5 & 6 & 5 & 8 & 8 & 8 & 12 & 24 & 21 & 28 \\
\hline Reina & 0 & 5 & 7 & 6 & 0 & 0 & 5 & 5 & 0 & 0 & 4 & 5 & 0 & 6 & 7 & 5 & 1 & 7 & 21 & 21 \\
\hline Karen & 0 & 2 & 2 & 3 & 1 & 3 & 3 & 4 & 0 & 2 & 1 & 0 & 1 & 2 & 2 & 4 & 2 & 9 & 8 & 11 \\
\hline
\end{tabular}

Note: Data is collected at four time points: 11 (prior to teacher preparation), T2 (end of teacher preparation), T3 (end of first year of full-time teaching), and T4 (end of second year of full-time teaching). 


\subsubsection{Qualitative and thematic analysis of CVA written comments. Qualitative}

analyses revealed other interesting shifts in teachers' perception, interpretation and decision making, while at the same time highlighting themes that were central in teachers' reflections. Prior to teacher preparation, participants' comments focused mostly on the teacher or on students' discipline and perceived engagement. These tendencies for novice teachers have already been well documented in the literature (Santagata \& Guarino, 2011; Star \& Strickland, 2008; van Es, 2010). At the end of teacher preparation, teachers began to attend to the students and to specific mathematical ideas. Comments evidenced more detail and coherence in their perception and interpretation driven from an effort to make sense of ways the videotaped teacher's instructional decisions impacted student learning. Comments often discussed the teacher-student verbal interactions and various tools (mathematical manipulatives and models) that can be used to explore and deepen students' understanding of mathematics concepts. Shifts in teachers' perception, interpretation, and decision making processes were characterized by two main themes that emerged from the analyses of these end-of-teacher-preparation CVA comments: "students" and "tools."

Students and tools remained central themes at the end of their first and second year of full-time teaching. Although the three participants showed some variations in their focus, overall changes over time evidenced improvement of teachers' abilities to: attend to important elements of instruction (i.e., student, teacher, mathematics content), offer evidence-based and detailed interpretations that take into account the specific mathematical ideas at the center of the teaching episodes, and make decisions about alternative strategies to enhance student learning. These findings are supported by research conducted by others on teacher noticing. For example, van Es 
(2011) introduced a framework for documenting teachers' development of noticing skills that includes dimensions and changes in quality of noticing similar to those highlighted here.

Table 3 below includes samples of CVA comments at each of the four points in time to provide a flavor for the nature of the comments and how they shifted in focus and changed in quality. These comments are in response to a video clip in which a student solved a two-digit multiplication problem and made a mistake. 
Table 3.

Participants' Sample CVA Comments at Time 1-Time 4

Time CVA Comment

T1 The girl was able to confidently answer how to solve the math problem. The teacher was able to explain the mistake that she made and all of the students seemed to be able to grasp the idea, which is heard through the students' verbal responses.

$\mathrm{T} 2 \quad$ The teacher is giving the student the opportunity to orally work out the problem as she records her responses on the board. She only comments with "alright" or "okay" and does not say whether it is right or wrong while the student is explaining. Only after the student has finished her explanations does the teacher open it up to the whole class for discussion. The teacher starts with some positive feedback with the student's work before directing the discussion into another direction. The teacher erases the student's solution and then works together with the class to solve the problem again. I think the teacher should have kept the student's work on one side as she re-did the problem to show students how the answers were.

T3 The students hove memorized the steps for multiplying 2 digit numbers. The teacher says the student is wrong, however does not ask the students what is wrong, but instead just tells them. The students will not know why they are doing what they are doing or why they need to add a zero. There is no conceptual understanding being taught in this lesson.

T4 The teacher did a good job at explaining the steps to the algorithm, but did not address place value as much. I would not stop the lesson there and go back and talk about why the $O$ has to be there, because it's showing the next place value of 10 where 0 has to be in the O's column. Also, I think the next discussion should include more student talk, where students collaborate with one another of why the 0 is there. This will give students an opportunity to have individual responses and therefore, help the teacher get a better idea of individual progress and can adjust and differentiate her teaching accordingly. 


\subsection{Interviews}

The interview data differed from the written CVA commentaries in a few important ways: teachers' were asked to reflect on their own teaching (rather than on the teaching of others), their reflections were about a whole lesson observed by the interviewer (rather than about short video clips), and the semi-structured character of the interview allowed the participant and the researcher to interact around the questions being asked and requests for clarification helped to understand teachers' comments more in depth. Interview data also helped to understand participants' reasoning about teaching in context in that it became clear that the communities to which teachers belonged also contributed to their perception, interpretation, and decision making. Data triangulation and comparative analysis of interview transcripts highlighted three themes. Two were the same themes that emerged from the CVA comments: the interviews well documented ways students and tools were central to teachers' perception, interpretation, and decision making. Teacher participation across professional communities emerged as a third theme intrinsic to teacher competence and its development. Teachers referred, explicitly and implicitly, to knowledge, beliefs, norms, and practices of the teacher education program community they attended, of the community of teachers and leadership at their school, and of other communities they entered through formal or informal professional development. In the following sections, we will discuss each theme and use interview quotes as illustration.

3.2.1 Students as sources of learning for teachers. Students were a central focus of participants' lesson reflections. Teachers discussed lesson effectiveness in terms of its impact on student learning and in relation to their ability to elicit and build on student thinking. This focus was also central to their discussion of lesson improvements. Student learning was seen as the most important outcome of their work and as a source of information about their competence. 
The following interview excerpts illustrate this theme. Here, Tracy was asked to reflect on her lesson on the conversion of a mixed number into an improper fraction.

Um, not so well. Only because the students didn't reach the goal ... I had to change a little bit my plan while I was teaching to fit their needs, because what I noticed is that they- so they weren't getting, even yesterday when we were doing equivalent fractions, they were still a little iffy on the conceptual understanding. Because I know that when I brought in the procedural thinking ... You know, they understood that, in the way that I was directly telling them, this is the strategy, or this is the way to do it, but, when asking to explain or even talk about showing it in different ways, they had a bit of trouble. So I anticipated that today - I wanted to keep going just to see because I was looking at the data from their quizzes yesterday - at the end of every lesson I always give that threequestion quiz - and it seemed like there was enough understanding that we could at least discuss this and explore it. (Tracy, year 1, visit 1)

Tracy based her analysis of the lesson effectiveness on evidence of students' progress. She also mentioned the prior lesson and explained how the students' understanding from the lesson prior influenced her planning of today's lesson. Her response demonstrates a close attention to students' thinking and a distinction between evidence of conceptual versus procedural understanding. At the end of her first year of full-time teaching, Tracy discusses her experience as "experimenting" and "learning from" students.

...it kind of continuously went up and down, and um, it was a lot of experimenting. I think that's the best way I can describe it. Because there were times when I would try something new and it would work so well and I would feel so confident and like, yes I'm doing something right, you know, I can see it, my evidence is right in front of me, it's in 
my kids. And then there would be days where I'll try something and it's just, a complete disaster. So it was a lot of experimenting. And um, a lot of learning from them [the students] too, you know? (Tracy, year 1, visit 3)

Over time across the six lesson reflections, the student theme remained present. Participants' attention to students grew in sophistication through time as interpretation of students' mathematical thinking and decision making (i.e., consideration of strategies to unveil and extend student thinking) became more specific. For example, in the case of Tracy, in the first year, her reflections discussed mainly one source of evidence of student learning — the "quick checks," a three or four question quiz administered at the end of the lesson. Her discussion of student learning on these types of assessments was often limited to the percentage of correct responses. In the second-year reflections, her discussion of student learning included a variety of sources of evidence that were used throughout the lesson to gauge student progress (i.e., she referred to: her circulating around the classroom to observe and record student strategies during students' exploration of a task; probing student thinking through the use of questioning to inform instruction; and documenting student strategies publically to promote student self-monitoring). The excerpts below illustrate these changes. Tracy discusses an assessment she created. I did from scratch [created lesson plan], so I created my own kind of structure with, you know, strategy one: with a partner, strategy two: independently. And on the back [of the paper] is where they have the independent work and explanation and reflection (Tracy, year 2, visit 3).

3.2.2 Tools as artifacts to access and develop student mathematical thinking. Another focus of teachers' reflections were tools to elicit and facilitate student thinking/learning during teaching. Comments centered on classroom discourse as a tool through which teaching and 
learning mathematics is performed. Children's talk was discussed as a tool to evaluate their mathematical understanding and to differentiate between children's conceptual understanding of operations versus procedural fluency. The ways they, as teachers, used classroom discourse was discussed in terms of whether it succeeded in making explicit student thinking and in deepening students' understanding of the mathematics identified in the lesson learning goals. Other tools that were discussed were specific visuals and models to support students' conceptual development and to assess students' understanding, such as ten frames, number lines, and unifix cubes.

We will illustrate this theme through quotes from interviews conducted with Reina. In the excerpt below, Reina discusses a lesson she just taught to kindergarteners (i.e., 5 or 6 year olds) on the meaning of the number 4. She explains how she used different visual tools to build students' reasoning between numbers and quantities:

So, like I've been saying we've been doing all the numbers, 0, 1, 2, 3, and then we did 4 today. And just looking at different ways to represent 4 to make sure they really understand what 4 is and different ways that you see it. You see it [the number 4] around, you see it on time, you see it in money, you see it in towers, and shapes, and also through the ten frame, and then also the beads. So later too, I want to introduce, I kind of did the number line once with them, but later on, I want to build that in as well. (Reina, Year 2, visit 1)

The next excerpt illustrates Reina's use of tools to reveal students' understanding and problem solving. She discusses a lesson in which students were given a number line to solve a word problem. 
I do see it and I can, I can understand better --oh this is what it is and I'm really trying to look to see what are they thinking? Even today with the number line ... or what they do. I'm always trying to think: "what are you thinking and why are you doing it that way? And how did you- why did you do that, what are they thinking?" (Reina, Year 2, visit 3) When reviewing teacher reflections across the six lessons, it became apparent that tools served as a vehicle for teachers to deepen their knowledge of children's solution strategies and mathematics understandings. In other words, tools helped teachers to refine their perception and interpretation of children's understandings and helped them make decisions about next steps. Teachers' use of tools became increasingly deliberate: they discussed selection of specific tools to achieve particular goals, and affordances and limitations of certain tools. For example, in the case of Reina, lesson reflections indicated that she considered an important aspect of her competence the ability to use tools appropriately. She also discussed tools as essential to her ability to access student thinking. Over time, her discussions of ways her students used specific tools and what that told her about student understanding became more sophisticated. In the following excerpt, Reina discusses the use of the ten-frame to encourage students to see relationships between numbers (i.e., eight is five and three and two less than ten) and to develop more sophisticated counting strategies (i.e., from counting on to counting back).

Well with the ten frame, I thought it was only in the first group did the students start taking away. So they said "10," they said, "this would be 8, this would be 9, 10." Only in the first group did they do that; the other ones are still adding them together. (Reina, year 2, visit 1)

3.2.3 Communities as intrinsic to teacher competence. The third theme that emerged from the analyses of the interviews, and that was unique to this data source, were various 
communities to which teachers belonged. Teachers' perception, interpretation, and decision making were shaped by beliefs supported by the particular communities they engaged with (e.g., grade-level colleagues, professional development groups, mentor teachers, and teacher preparation program instructors). Specific teaching scripts that were valued within a particular community served as lenses through which teachers perceived and interpreted their practices. They mentioned slogans commonly used in the United States to describe lesson formats and pedagogical approaches, such as "I do, we do, you do," or mentioned particular approaches to mathematics teaching such as Cognitive Guided Instruction (Carpenter, et al., 1999).

For example, Karen reflected on the extent to which her teaching aligned with the approach required by her school leadership. This approach defined for her a vision of competence against which she continuously measured her own teaching practices. At the same time, Karen's discussion of her competence also reflected her participation in the community of the teacher preparation program she attended. She was in contact with another teacher who graduated from the program with whom she often talked about her teaching experiences. Her perception and interpretation of classroom events therefore sometimes reflected this community's view of competent mathematics teaching.

In the excerpt below, Karen describes the instructional approach promoted by her school leadership:

...brain theory, that's what they [her school leadership] want: 5 minutes direct instruction, 15-20 minutes of guided practice, and then independent practice ... (Karen, year 1, visit 3).

Soon after, in the same interview, she discusses what she learned during teacher preparation and her difficulty in understanding how she could apply the instructional approach promoted by her math methods instructor in her school setting. 
It [the methods course] got me thinking about a new way [to teach math]. You know we were-I was taught traditionally where you're supposed to memorize this and that's how you know... But the methods instructor really broke it down and that's different, like decomposing numbers and such ... it helped ... Opened up a new thing for me, but I'm not so sure I could apply it to this particular setting.

Communities continued to be central to teacher reflections overtime. They shaped what teachers attended to, how they interpreted classroom events, and how they made instructional decisions. Teachers became more competent members of these communities or learned to negotiate their role in the community when their values differed.

\section{Discussion of Findings and Conclusions}

The findings thus support the inclusion of perception, interpretation, and decision making processes in the conceptualization of teacher competence, as proposed by Blömeke and colleagues (2014). Both sets of data revealed that these processes revolved around student thinking and learning. Various tools were also mentioned that helped teachers to access student mathematical thinking and to move their students' and their own learning forward. In addition, it is through careful attention to the details of students' mathematical thinking and learning (supported by tools) and through interpretations of student work and utterances that teachers came to decisions about what next steps to take in instruction.

While at each moment in time teachers' own understanding of mathematical ideas and their beliefs about children's mathematics learning informed their sense making, interviews also highlighted how teachers sometimes made decisions based on particular instructional approaches recommended by their colleagues or required by their school leadership. In other words, the context in which they worked and other professional communities in which they engaged also 
served as lenses for attending to and interpreting their practices and for making decisions. The instructional approaches promoted by teachers' communities did not always align with teachers' own beliefs about best practices. During the first year, teachers were observed adopting methods suggested to them, sometimes alongside conflicting approaches they seemed to prefer (in most cases, these were approaches learned during teacher preparation). During the second year, teachers took a stance and chose instructional approaches that better matched their beliefs. To account for the influence of teacher communities on participants' instructional decisions, we included communities in the conceptualization of teacher competence.

Second, our analyses show that perception, interpretation, and decision making, as measured by the CVA and evidenced by increases in CVA scores, improved in sophistication over time. At the same time, by focusing on student thinking and learning, teachers learned a great deal about their students and about mathematics teaching: ways students learn mathematics, particularly challenging mathematical ideas, mathematical representations that can be used to move student thinking forward, effective use of classroom discourse, and so on. This is in line with work conducted by Hiebert and colleagues (Hiebert, Morris, Berk, \& Jansen, 2007). These authors argue that when teachers engage in perception, interpretation, and decision making with specific student learning goals in mind, they learn from their teaching and thus improve their practices over time.

These findings prompted us to revise the competence model we started with. While Blömeke and colleagues’ present a more linear conceptualization of competence in which dispositions (i.e., cognition and affect/motivation) are seen as influencing situation-specific skills, which then in turn influence classroom behavior, our data suggest a different model. Situation-specific skills function as the processes through which knowledge and beliefs become 
relevant in practice. At the same time, changes in competence would not be possible if teachers did not deliberately attend to and interpret practice and make decisions that create new knowledge and new beliefs. Therefore, practice offers opportunities both to refine perception, interpretation, and decision making and to increase one's knowledge and change one's beliefs. In other words, when teachers deliberately design lessons to access and examine student mathematical thinking, their subsequent reflections on their teaching is enhanced by specific evidence of student thinking they were able to collect during teaching. This bi-directionality between knowledge, beliefs, skills and practice reflects prior research as well. Kazemi \& Hubbard (2008) for example discuss the interplay between professional development settings and classroom practice. Sherin \& van Es (2009) examine the development of professional vision as emerging from close analysis of student thinking in video clips of teachers' lessons. Franke et al. (2005) discuss how attention to student mathematical thinking during teaching creates opportunities for teacher generative learning. Finally, Putnam \& Borko (2002) argue that a situative perspective allows us to see classrooms as powerful contexts for teacher learning.

Figure 3 illustrates our resulting model. Knowledge and beliefs overlap with classroom practice, and perception, interpretation, and decision making skills are at the center of the overlapping space. These processes are also displayed as a cycle with students, tools, and teacher communities in the middle. This is to take into account the fact that teachers were observed engaging in the process of attending to students and tools and interpreting classroom experiences in order to make decisions about next steps. These decisions were also informed by instructional approaches promoted by the communities they belonged to. We also used terms differently from Blömeke and colleagues to be consistent with ways we have previously written about teacher dispositions and classroom behavior (Santagata \& Guarino, 2011). As it relates to 
experiences teachers have in the classroom, we prefer to use the term "practices" instead of "behavior" as this term captures its situated nature and the context in which behavior occurs as intrinsic to teachers' experiences. As for the use of the terms "knowledge" and "beliefs" instead of "dispositions" (and cognition and affect/motivation), as mentioned above, this reflects our consideration of what teachers know and believe, not as purely belonging to them and located in their mind, but as socially and contextually negotiated. In this sense, we embrace a situated perspective of teacher competence (Borko, 2004). 


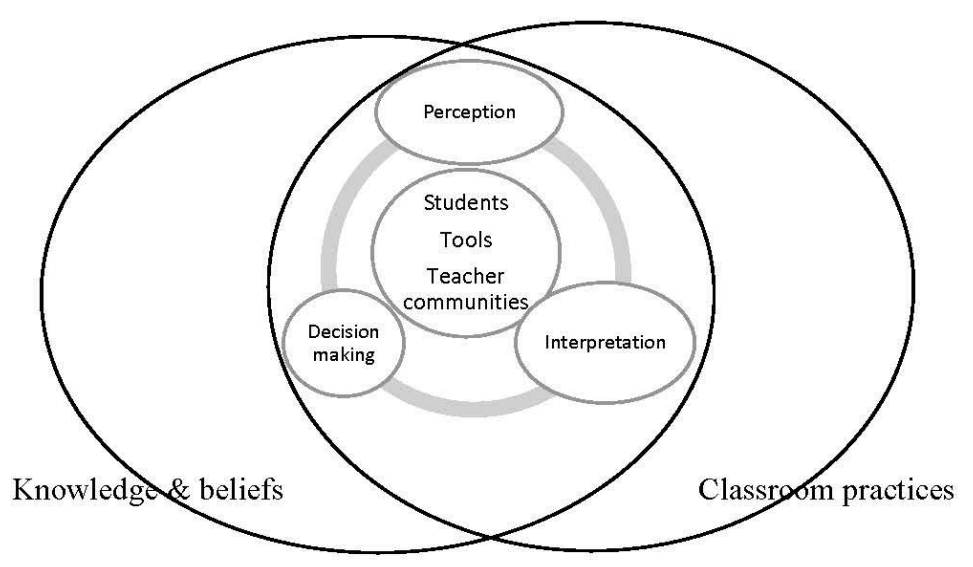

Figure 3. Revised model of teacher competence. 
Part of the knowledge and beliefs area does not overlap with classroom practice. We speculate that this area represents knowledge and beliefs that are not activated during teaching. These may be triggered in the future, but do not affect practice at the present moment. Prior research supports this representation. Usable knowledge of teaching (as measured by the CVA) for example was found to only partially overlap with mathematics knowledge for teaching (as measured by a multiple-choice survey designed by Hills and colleagues (2005)), indicating that teachers may possess knowledge that is not triggered while they teach (Kersting, Givvin, Thompson, Santagata, \& Stigler, 2012). We also speculate that teacher competence includes an area of classroom practice that does not overlap with knowledge and beliefs. This area represents practices teachers may engage in without deliberate reflection. This happens when teachers implement in their classrooms teaching strategies they have experienced as students with minimal awareness of pedagogical goals or alternatives, or, more generally, when their practices do not reflect deliberate planning; rather they are the product of cultural routines (Santagata, 2005). U.S. teachers, for example, may begin a math lesson with a warm up (i.e., a series of review problems for students to work on individually) — a routine activity typical of the U.S. math lesson script (Stigler \& Hiebert, 1999).

The central area represents the overlap of knowledge and beliefs and classroom practice and revolves around the cyclical processes of perception, interpretation, and decision making, which we argue are at the core of teacher competence. This is a space of deliberate practice and reflection, in which knowledge and beliefs encounter classroom practice. A space in which teachers attend to students and tools, interpret what happens, and make decisions for the future. That is also a space in which communities become an intrinsic part of who teachers are and what they decide to do in their classrooms. 
According to this model, teacher competence seems better defined as a complex interaction of situated knowledge, beliefs, and practices that can be understood only in the specific context in which teachers work. Knowledge of the mathematics for example needs to become relevant to the situation at hand to be evident in teacher behavior. Community pressures might shape a teacher's instructional choices and even result in a behavior that contradicts knowledge a teacher might show in a different situation.

The impact of professional development has typically been framed has a chain of effects from changes in knowledge and skills that cause changes in classroom teaching and subsequently in student learning. The model of competence we propose suggest that situation-specific skills (perception, interpretation, and decision making) should take centrality when supporting teachers and their learning. The generative power of perception, interpretation and decision making was in fact evident in the case studies we examined.

In addition to contributing to the conceptualization of teacher competence, this study examined the use of a video-based measure to assess teacher competence, the CVA survey. Because teachers were asked to react to video clips of teaching episodes, their competence was assessed in the context of a specific teaching situation. The CVA scores were able to capture changes in competence that were evidenced in the qualitative analyses of CVA comments and in teachers' interviews. It thus shows potential as a measure that can be used in studies that examine competence over time or changes in competence as a result of professional development experiences. The only aspect that the CVA was not able to capture is the social context in which teachers work because the video clips are drawn from other teachers' classrooms. According to our model, it is thus possible for a gap to remain between competence teachers show through the CVA and competence they demonstrate in their classrooms where community values and 
practices may inform some of their instructional decisions. When examining the outcomes of teacher preparation and professional development, researchers may want to consider a videobased measure that includes in addition to clips of other teachers' classrooms, clips of teachers' own classrooms. Teachers could upload the video clips on a protected site and their selfreflections could be scored according to pre-determined rubrics. Teachers' school context and community pressures could also be examined by asking teachers to answer accompanying survey questions about their context and communities.

\section{Acknowledgments}

This research was supported by the National Science Foundation (Research and Evaluation on Education in Science and Engineering (REESE) Program) under Grant DRL-0953038. Any opinions, findings, and conclusions expressed in this material are those of the authors and do not necessarily express the views of the National Science Foundation. The authors thank the participating teachers for opening their classroom doors to us and for engaging in deep conversations about their practices and their professional lives.

\section{References}

Ball, D. L., Thames, M.H., \& Phelps, G. (2008). Content knowledge for teaching: What makes it special? Journal of Teacher Education, 59, 398-407.

Blömeke, S., Gustafsson, J. E., \& Shavelson, R. (2014). Beyond dichotomies: Viewing competence as a continuum. Zeitschrift für Psychologie.

Blömeke, S., Kaiser, G., \& Lehmann, R. (2010). TEDS-M 2008. Professionelle Kompetenz und Lerngelegenheiten angehender Mathematiklehrkrä für die Sekundarstufe I im internationalen Vergleich. München: Waxman. 
Blömeke, S., Hsieh, F., Kaiser, G. \& Schmidt, W. H. (Eds.) (2014). International perspectives on teacher knowledge, beliefs and opportunities to learn. TEDS-M Results. Dordrecht: Springer.

Borko, H. (2004). Professional development and teacher learning: Mapping the terrain. Educational researcher, 33(8), 3-15.

Borko, H., Roberts, S. A., \& Shavelson, R. (2008). Teachers' decision making: From Alan J. Bishop to today. In P. Clarkson \& N. Presmeg (Eds.), Critical issues in mathematics education: Major contributions of Alan Bishop (pp.37-67). Netherlands: Springer.

Calderhead, J. (1996). Teachers: Beliefs and knowledge. In D. C. Berliner \& R. C. Calfee (Eds.), Handbook of educational psychology (pp. 709 - 725). New York, NY: Macmillan.

Carpenter, T., Fennema, E., Franke, M.L., Levi, L., \& Empson, S. B. (1999). Children's mathematics: Cognitively guided instruction. Portsmouth, NH: Heinemann.

Chi, M. T. H. (2011). Theoretical Perspectives, Methodological Approaches, and Trends in the Study of Expertise. In Y Li, \& G. Kaiser (Eds.), Expertise in Mathematics Instruction: An International Perspective (pp. 17-39). New York: Springer.

Corbin, J., \& Strauss, A. C. (2007). Basics of qualitative research: Techniques and procedures for developing grounded theory (3rd ed.). Thousand Oaks: Sage.

Chetty, R., Friedman, J.N., \& Rockoff, J.E. (2011). The long term impacts of teachers: Teacher value-added and student outcomes in adulthood. NBER Working Paper 17699.

European Mathematical Society - Education Committee (2012, March). It is necessary that teachers are mathematically proficient, but is it sufficient? Solid findings in mathematics education on teacher knowledge. Newsletter of the European Mathematical Society, 83, 46-50. 
Fives, H., \& Buehl, M. M. (2012). Spring cleaning for the “'messy”'construct of teachers' beliefs: What are they? Which have been examined? What can they tell us? In K. R. Harris, S. Graham, \& T. Urdan (Eds.), Individual differences and cultural and contextual factors (pp. 471-499). Washington, DC: APA.

Franke, M. L., Carpenter, T. P., Levi, L., \& Fennema, E. (2001). Capturing teachers' generative change: A follow-up study of professional development in mathematics. American educational research journal, 38(3), 653-689.

Glaser, B. G., \& Strauss, A. L. (1968). The discovery of grounded theory: Strategies for qualitative research. New Brunswick, NJ: Aldine Transaction.

Gutiérrez, R. (2013). The sociopolitical turn in mathematics education. Journal for Research in Mathematics Education, 44, 37-68.

Hiebert, J., Morris, A. K., Berk, D., \& Jansen, A. (2007). Preparing teachers to learn from teaching. Journal of Teacher Education, 58, 47-61.

Hiebert, J., Stigler, J. W., Jacobs, J. K., Givvin, K. B. Garnier, H., Smith, M., Kersting, N., Manaster, A., Tseng, E., Etterbeek, W., Manaster, C., Gonzales, P. and Stigler, J.W. (2005). Mathematics teaching in the United States today (and tomorrow): Results from the TIMSS 1999 Video Study. Educational Evaluation and Policy Analysis, 27(2), 111132.

Hiebert, J., Morris, A. K., Berk, D., \& Jansen, A. (2007). Preparing teachers to learn from teaching. Journal of Teacher Education, 58, 47-61.

Hill, H.C., Blunck, M.L., Charalambos, Y.C., Lewis, J.M. Phelps, G.C., Sleep, L., \& Ball, D. L. (2008). Mathematical Knowledge for Teaching and the Mathematical Quality of Instruction: An exploratory study. Cognition and Instruction, 26(4), 430-511. 
Hill, H.C., Rowan, B. \& Ball, D.L. (2005). Effects of teachers' knowledge for teaching on student achievement. American Educational Research Journal, 42(2), 371-406.

Jacobs, V. R., Lamb, L. C., Philipp, R. A., \& Schappelle, B. P. (in press). Deciding how to respond on the basis of children's understandings. In M. G. Sherin, V. R. Jacobs, \& R. A. Philipp (Eds.), Mathematics teacher noticing: Seeing through teachers' eyes (pp. 97116). New York: Routledge.

Jaworski, B. (2006). Theory and practice in mathematics teaching development: Critical inquiry as a mode of learning in teaching. Journal of Mathematics Teacher Education, 9(2), 187211.

Kaiser, G., Blömeke, S., Busse, A., Döhrmann, M. \& König, J. (2014). Professional knowledge of (prospective) mathematics teachers - Its structure and its development. In P. Liljedahl, C. Nicol, S. Oesterle \& Dr. Allan (Eds.), Proceedings of the joint meeting of PME 38 and PME-NA 36, Vol.1 (pp. 35-50). Vancouver: PME.

Kazemi, E., \& Hubbard, A. (2008). New directions for the design and study of professional development attending to the coevolution of teachers' participation across contexts. Journal of Teacher Education, 59(5), 428-441.

Kersting, N. (2008). Using video clips as item prompts to measure teachers' knowledge of teaching mathematics. Educational and Psychological Measurement, 68, 845-861.

Kersting, N., Givvin, K., Thompson, B., Santagata, R., \& Stigler, J. (2012). Measuring usable knowledge: Teachers' analyses of mathematics classroom videos predict teaching quality and student learning. American Education Research Journal, 49(3), 568-589.

Miles, M.B., \& Huberman, A.M. (1994). Qualitative Data Analysis. Thousand Oaks, CA: Sage Publications. 
Putnam, R. T., \& Borko, H. (2000). What do new views of knowledge and thinking have to say about research on teacher learning?. Educational researcher, 29(1), 4-15.

Santagata, R. (2009). Designing video-based professional development for mathematics teachers in low-performing schools. Journal of Teacher Education, 60(1), 38-51.

Santagata, R., \& Guarino, J. (2011). Using Video to Teach Future Teachers to Learn from Teaching. ZDM -The International Journal of Mathematics Education, 43(1), 133-145.

Santagata, R., Zannoni, C. \& Stigler. (2007). The Role of Lesson Analysis in Pre-Service Teacher Education: An Empirical Investigation of Teacher Learning from a Virtual Video-Based Field Experience. Journal of Mathematics Teacher Education, 10,(2), 123140.

Sherin, M.G., Jacobs, V.R., \& Philipp, R.A. (Eds). (2011). Mathematics teacher noticing: Seeing through teachers' eyes. New York: Routledge.

Sherin, M.G. \& van Es, E.A. (2009). Effects of video club participation on teachers' professional vision. Journal of Teacher Education, 60, 20-37.

Shulman. L. (1987). Knowledge and teaching: Foundations of the new reform. Harvard Educational Review, 57, 1-22.

Star, J.R., \& Strickland, S.K. (2008) Learning to observe: using video to improve preservice mathematics teachers' ability to notice. Journal of Mathematics Teaching Education, 11, 107-125.

Thompson, A. (1992). Teachers' beliefs and conceptions. In D. Grouws (Ed.), Handbook of research on mathematics teaching and learning (pp. 127 -146). New York, NY: Macmillan.

Tschannen-Moran, M. , \& Woolfolk-Hoy, A. (2001) .Teacher efficacy: Capturing an elusive 
construct. Teaching and Teacher Education, 17, 783 - 805.

van Es, E. A. (2011). A framework for learning to notice student thinking. In M.G. Sherin, V. Jacobs, \& R. Philipp (Eds.) Mathematics teacher noticing: Seeing through teachers' eyes (pp. 134-151). Routledge: New York.

Yeh, C. \& Santagata, R. (2014). Pre-Service Teachers' Learning to Generate Evidence-Based Hypotheses about the Impact of Mathematics Teaching on Learning. Journal of Teacher Education. DOI: 10.1177/0022487114549470

Yin, R.K. (2003). Case study research: Design and methods (4th edition). Thousand Oaks, CA: SAGE Publications. 